\title{
Vitamin E: action, metabolism and perspectives
}

\author{
E. Herrera and C. Barbas \\ Facultad de Ciencias Experimentales y Técnicas, Universidad San Pablo-CEU, \\ 28668 Boadilla del Monte, Madrid (Spain)
}

(Received on October 5, 2000)

E. HERRERA and C. BARBAS. Vitamin E: action, metabolism and perspectives (minireview). J. Physiol. Biochem., 57 (1), 43-56, 2001.

Natural vitamin E includes four tocopherols and four tocotrienols. RRR- $\alpha$-tocopherol is the most abundant form in nature and has the highest biological activity. Although vitamin $\mathrm{E}$ is the main lipid-soluble antioxidant in the body, not all its properties can be assigned to this action. As antioxidant, vitamin $\mathrm{E}$ acts in cell membranes where prevents the propagation of free radical reactions, although it has been also shown to have pro-oxidant activity. Non-radical oxidation products are formed by the reaction between $\alpha$-tocopheryl radical and other free radicals, which are conjugated to glucuronic acid and excreted through the bile or urine. Vitamin $\mathrm{E}$ is transported in plasma lipoproteins. After its intestinal absorption vitamin $\mathrm{E}$ is packaged into chylomicrons, which along the lymphatic pathway are secreted into the systemic circulation. By the action of lipoprotein lipase (LPL), part of the tocopherols transported in chylomicrons are taken up by extrahepatic tissues, and the remnant chylomicrons transport the remaining tocopherols to the liver. Here, by the action of the “ $\alpha$-tocopherol transfer protein", a major proportion of $\alpha$-tocopherol is incorporated into nascent very low density lipoproteins (VLDL), whereas the excess of $\alpha$-tocopherol plus the other forms of vitamin $\mathrm{E}$ are excreted in bile. Once secreted into the circulation, VLDL are converted into IDL and LDL by the action of LPL, and the excess of surface components, including $\alpha$-tocopherol, are transferred to HDL. Besides the LPL action, the delivery of $\alpha$-tocopherol to tissues takes place by the uptake of lipoproteins by different tissues throughout their corresponding receptors. Although we have already a substantial information on the action, effects and metabolism of vitamin E, there are still several questions open. The most intriguing is its interaction with other antioxidants that may explain how foods containing small amounts of vitamin $\mathrm{E}$ provide greater benefits than larger doses of vitamin $\mathrm{E}$ alone.

Key words: Vitamin E, $\alpha$-Tocopherol, Antioxidants, Lipoproteins.

Correspondence to: E. Herrera (Tel.: +34-91-3724730; Fax:+34-91-3510496; e-mail: eherrera@ ceu.es). 
In 1922, Evans and Bishop (34) discovered vitamin $\mathrm{E}$ when a dietary factor was found to be absent in rancid fat that was essential to avoid a deficiency syndrome in pregnant rats, in which fetal resorption was the most characteristic manifestation. The substance lacking in such a diet which was able to revert the symptoms was present in fresh salad and wheat germ oil, was lipid-soluble and has been identified as a group of potent antioxidants. Natural vitamin $\mathrm{E}$ includes four tocopherols $(\alpha, \beta$, $\delta)$ and four tocotrienols $(\alpha, \beta, \gamma \delta$ ) all derived from 6-chromanol. As shown in figure 1, the first group carries a saturated isoprenoid C-16 and three chiral centres with configuration $\mathrm{R}$ at positions 2,4 ' and 8', whereas the second group has a triple unsaturated side chain at positions 3', 7' and 11'. The members of either

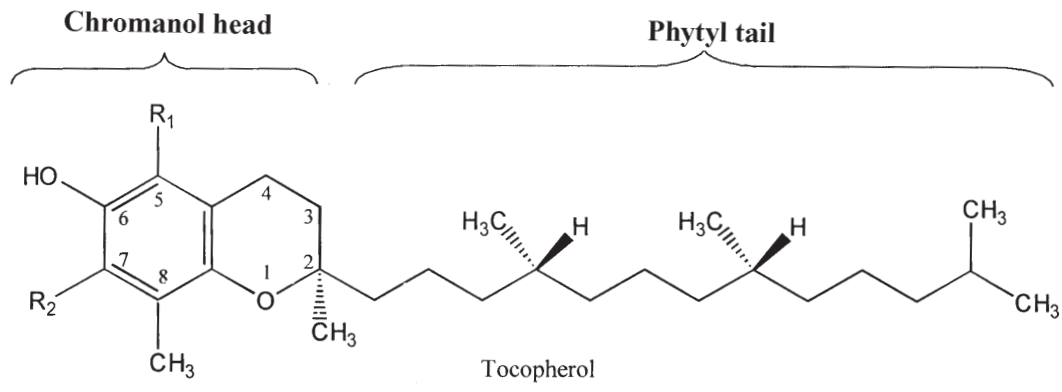<smiles>[R]c1c(C)c2c(c([R])c1O)CC[C@@](C)(CC/C=C(\C)CC/C=C(\C)CCC=C(C)C)O2</smiles>

\begin{tabular}{l|l|c}
$\mathbf{R}_{\mathbf{1}}$ & $\mathbf{R}_{\mathbf{2}}$ & Compound \\
\hline $\mathrm{CH}_{3}$ & $\mathrm{CH}_{3}$ & $\alpha$ \\
\hline $\mathrm{CH}_{3}$ & $\mathrm{H}$ & $\beta$ \\
\hline $\mathrm{H}$ & $\mathrm{CH}_{3}$ & $\gamma$ \\
\hline $\mathrm{H}$ & $\mathrm{H}$ & $\delta$
\end{tabular}

Fig. 1. Structure of natural components of vitamin $E$. 
group are designated $\alpha, \beta \gamma$ and $\delta$ in function of the number and position of the methyl groups attached to the aromatic ring (Fig. 1). There is also vitamin $\mathrm{E}$ of synthesis, made up of approximately an equal mixture of 8 steroisomer forms of $\alpha$-tocopherol. The most abundant form of vitamin $\mathrm{E}$ in nature is $\mathrm{RRR}$ - $\alpha$-tocopherol (72), that has the highest biological activity on the basis of rat fetal-resorption assay (17) and reverses vitamin E deficiency symptoms in humans $(68,73)$. Biological and antioxidant activities are not coincident among the different vitamin $\mathrm{E}$ forms. Thus, whereas $\gamma$-tocopherol (a form that is abundant in human diet) has about half of the antioxidant capacity of $\alpha$-tocopherol activity (18), it only has one tenth of its biological activity (17) and although the various synthetic $\alpha$-tocopherol forms have different biological activities, they have similar antioxidant activity.

The 8 isomers of vitamin $\mathrm{E}$ are widely distributed in nature. Vitamin $\mathrm{E}$ has been detected in all plants in different compositions and there is a strong correlation between its content and the amount of unsaturated fatty acids in plant oils(9), suggesting that vitamin $E$ represents one of the most abundant antioxidants in plant tissues. Interestingly, olive oil, a major component of the "Mediterranean diet", contains small amounts of vitamin E compared to other vegetable oils $(57,72)$, but it has been recently shown in rats that endogenous levels of $\alpha$-tocopherol are preserved following olive oil intake (1) probably due to its high content of monounsaturated fatty acids which are more resistant to peroxidation than polyunsaturated fatty acids. In contrast to plants, mammalian tissues contain almost exclusively $\alpha$-tocopherol, the highest content found in those tissues with the higher lipid content and very specially in adipose tissue and adrenals, whereas the content in liver is much lower (55). Considering the high mass of adipose tissue (in the range of $13-19 \%$ of body weight [8]), this tissue constitutes the main store of vitamin $\mathrm{E}$ in the body. However, $\alpha$-tocopherol levels are normally measured in plasma in order to determine the vitamin $\mathrm{E}$ status of the subject, despite being in low concentrations $(0.5-1.6 \mathrm{mg} / \mathrm{dL}$ in normal population [19]).

\section{Actions and functions}

Although vitamin $\mathrm{E}$ is a potent lipidsoluble antioxidant, not all its properties can be assigned to this action $(4,7)$. The following properties are included among the supposed non-antioxidant molecular mechanism of $\alpha$-tocopherol:

- Prevention of spermatogenesis loss in males and fetal reabsorption in the rat (34, 91).

- Inhibition of $\alpha$-tropomyosin expression (2).

- Inhibition of scavenger receptors class A (SR-A) (79).

- Inhibitory action on protein kinases C $(5,61)$, which play a key role on the effects of vitamin $\mathrm{E}$ inhibiting cell proliferation in vascular smooth muscle (70).

- Up-regulation of the cytosolic phospholipase $\mathrm{A}_{2}$ and cyclooxygenase activities (24).

Antioxidant and pro-oxidant action.Vitamin E functions as a chain-breaking antioxidant that prevents the propagation of free radical reactions $(18,44,78)$, which are involved in several disease processes (cancer, cardiovascular disease, diabetes and aging among others). Despite its low concentration in cell membranes (less than one molecule of $\alpha$-tocopherol per 1000 of lipids), it is considered the main lipid sol- 
uble antioxidant in the body, although it has been also shown to have pro-oxidant activity (49). Figure 2 shows the scheme of polyunsaturated lipid peroxyl radical (PUFA-OO*) production in the lipid phase of the cell (membranes) and of part of the antioxidant, pro-oxidant and regeneration reactions of $\alpha$-tocopherol $(\mathrm{TocOH})$. One free radical chain reaction is initiated when one polyunsaturated fatty acid (PUFA) present in cell membrane phospholipids lose one hydrogen by reacting with a free radical $\left(\mathrm{R}^{*}\right)$, being converted into one free radical of polyunsaturated fatty acid (PUFA ${ }^{*}$ ) which reacts with oxygen to produce a peroxyl free radical of polyunsaturated fatty acid (PUFA-OO'). This free radical may take a hydrogen to other PUFA, which initiates its transformation into peroxyl radical and

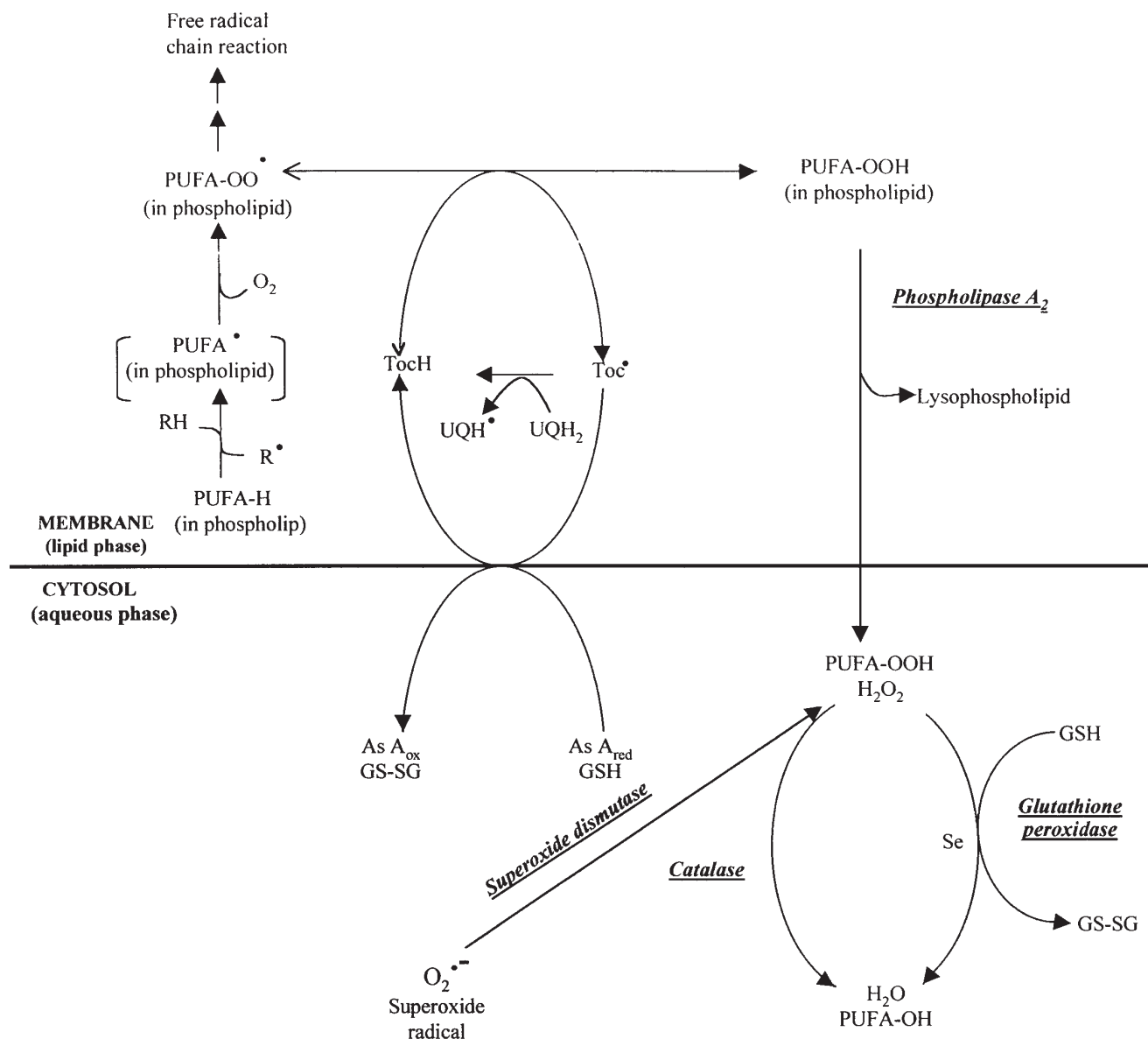

Fig. 2. Scheme of the interaction and synergism between antioxidant systems operating in membrane (lipid phase) and cytosol (aqueous phase) of the cell, with special attention to part of the antioxidant, pro-oxidant and regeneration reactions of tochopherol $(\mathrm{TocH})$.

Other details in the text. 
the repetition of this process constitutes the "free radical chain reaction", which may disturb the molecular structure of the membrane. As shown in figure 2, the reaction of PUFA-OO ${ }^{\bullet}$ and tocopherol $(\mathrm{TocH})$ results in the production of hydroperoxide polyunsaturated fatty acid (PUFA-OOH), which is no longer a free radical and the $\alpha$-tocopherol radical $\left(\mathrm{Toc}^{\bullet}\right)$. Toc ${ }^{\bullet}$ may also combine with PUFA-OOH and again produce PUFA$\mathrm{OO}^{\bullet}$ and this reaction may be considered part of the pro-oxidant action of $\alpha$-tocopherol (60). This pro-oxidant action is suppressed when TocH is regenerated by the reactions of $\mathrm{Toc}^{\bullet}$ with vitamin $\mathrm{C}$ (Lascorbic acid, AsA) together with the reduced form of glutathion (GSH) (58) at the interface of the cell membrane and the aqueous phase (cytosol), or with ubiquinol $\left(\mathrm{UQH}_{2}\right)$ within the cell membrane, all these reactions being essentially proton- or hydrogen-transfer reactions (Fig. 2). By the action of phospholipase $A_{2}$ on PUFA-OOH in membrane phospholipid, free-PUFA-OOH are released into the cytosol, whereby the action of the enzymatic systems of superoxide dismutase, catalase and glutathion peroxidase are converted into hydroxy polyunsaturated fatty acid (PUFA-OH) (Fig. 2).

Oxidation products of vitamin E.- Oxidation products of $\alpha$-tocopherol are formed by the reactions between $\alpha$-tocopheryl radical $\left(\mathrm{Toc}^{\circ}\right.$ ) and $\mathrm{PUFA}-\mathrm{OO}{ }^{\bullet}$ (or other radicals), producing PUFA-OOH plus a non-radical product of tocopherol, in which the chromane ring is transformed into no-radical products (53). These no-radical products of tocopherol are very variable and may be visualized in two groups (52) (Fig. 3). In the first group, the primary products correspond to $8 \mathrm{a}$ substituted tocopherones, which may subsequently hydrolyze to form $\alpha$-tocopheryl quinone $(\alpha-T Q)$, that may be converted to $\alpha$-tocopheryl hydroquinone $(\alpha-T H Q)$ by means of a two electron reduction. The second group consists of epoxytocopherones and epoxyquinones. Although in smaller proportion, the possibility also exists that two Toc may react to give dimeric forms (71). These products are conjugated to glucuronic acid and excreted through the bile or urine. In this way, once carried out its function, a substantial amount of $\alpha$-tocopherol is not reclycled either intact or transformed into those products and therefore, it has to be replaced in order to be present in the cell membrane (47).

A number of compounds derived from the oxidation of the phytyl side of tocopherol, leaving the chromanol structure intact, have been detected in urine either in their free form or as glucuronide conjugates. These compounds seem to be indicators of an excess in the tocopherol supply and include 2,5,7,8-tetramethyl2-( $\beta$-carboxyethyl)-6-hydroxychroman $(\alpha-\mathrm{CEHC})$, metabolite of $\alpha$-tocopherol (67, 69), 2,7,8-trimethyl-2-( $\beta$-carboxyethyl)-6-hydroxychroman ( $\gamma$-CEHC), metabolite of $\gamma$-tocopherol (89) and 2,8dimethyl-2-( $\beta$-carboxyethyl)-6-hydroxychroman $(\delta$-CEHC), metabolite of $\delta$ tocopherol (25) (Fig. 4). Since both $\alpha$ - and $\gamma$-tocopherols are the two most important members of the vitamin $\mathrm{E}$ family in human nutrition (13), the urinary excretion of both $\alpha$ - and $\gamma$-CEHC has been studied with special attention and it has been recently shown that the rate of urinary excretion of $\alpha$-CEHC is much less than that of $\gamma$-CEHC, the latter representing in its glucuronide conjugate form the major route of $\gamma$-tocopherol elimination in humans (76), whereas a mechanism exists to actively promote the retention of 
$\alpha$-tocopherol (see below). It has been proposed that $\gamma$-CEHC in urine has a physiological role in the urinary excretion of sodium (natriuresis) (89).

Vitamin $E$ and atherosclerosis.- Vitamin $\mathrm{E}$ has been involved in the prevention or treatment of several diseases, including hot flashes, hypercholesterolemia, fibro- cystic disease, hemolitic anemia, cancer, diabetes, diabetes pregnancy teratogenesis, resistance to infection, increase sexual potency and decrease aging $(38,87,90)$. Researches have placed specific emphasis on the effects of vitamin $\mathrm{E}$ in atherosclerosis and its complications, which is the major cause of premature death in the developed world. As recently reviewed

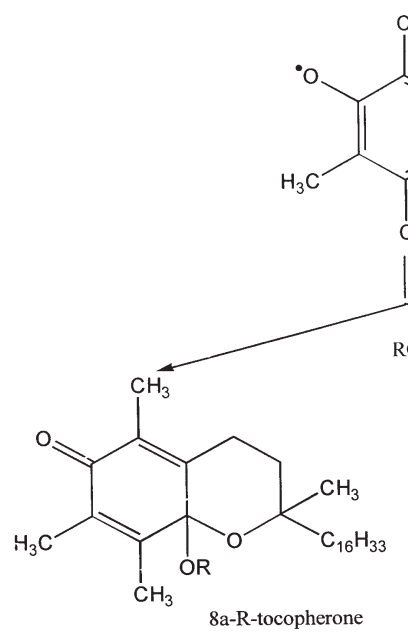<smiles>CCCCCCC(C)(O)CCC1=C(C)C(=O)C(C)=C(C)C1=O</smiles>

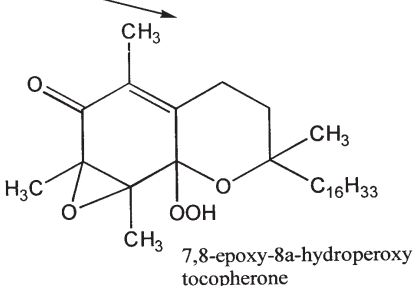

<smiles>CC1=C(CCC(C)([14CH3])O)C(=O)C2(C)OC2(C)C(=O)C1=O</smiles>

Fig. 3. Representative oxidation products of a-tocopherol formed in the reactions of $\alpha$-tocopheryl radical $(\alpha-$ $\mathrm{Toc}^{\bullet}$ ) with other radicals $\left(\mathrm{ROO}^{\circ}\right)$, including PUFA-OO`. Based on ref. 53. Other details in the text. 
(22), the protective effects of vitamin $E$ on lipoproteins and different cell types involved in atherosclerosis include:

- Inhibition of LDL oxidation (30, 63, 86).

- Inhibition of thrombin generation assembly (64).

- Enhancement of prostacyclin synthesis $(21,77)$.

- Up-regulation of the expression of cytosolic phospholipase $\mathrm{A}_{2}$ and cyclooxygenase in endothelial cells (24).

- Inhibition of agonist-induced monocyte adhesion in endothelial cells (35).

- Decreased endothelial expression of adhesion molecules induced by oxidized LDL (27).

- Inhibition of smooth muscle cells proliferation (6).
- Inhibition of platelet adhesion, aggregation and platelet release reaction (37).

- Reduction of leukotriene synthesis (23).

- Reduction of monocyte adhesion (29).

The formation of oxidized LDL in the subendothelial space of the artery wall is now accepted to be a causative action in the development of atherogenesis and therefore the potential anti-atherogenic role of the antioxidant actions of vitamin $\mathrm{E}$ have received much attention. However, although the benefits of vitamin $\mathrm{E}$ in the treatment of coronary heart disease have been reported for more than 50 years ago (88) and from there on many studies have supported such claim, recent studies have questioned the protective effect of<smiles>[R]c1c(C)c2c(c([R])c1O)CC[C@@](C)(CCC[C@H](C)CCC[C@@H](C)CCCC(C)C)O2</smiles>

Fig. 4. Conversion of tocopherols into their respective CEHC forms found in urine. 
vitamin $\mathrm{E}$ on atherosclerosis and have shown diverse roles for $\alpha$-tocopherol in LDL oxidation, displaying neutral, anti-, or pro-oxidant activity under various conditions $(12,62,75)$. Although the regular intake of foods rich in vitamin $\mathrm{E}$ is associated with decreased events due to cardiovascular disease (40), the benefit of large dose vitamin $\mathrm{E}$ supplementation is less clear. Results from large-scale randomized trials in humans are inconclusive (39): beneficial (74) and adverse (80) effects have been reported. As recently reviewed, animal studies are also inconclusive (85): from 32 studies in animals fed standard chow, 5 clearly suggested that dietary supplementation with vitamin E decreased, while 4 studies promoted atherosclerosis, whereas in 4 out of 5 studies in vitamin Edeficient animals, vitamin $\mathrm{E}$ decreased atherosclerosis. Although these findings are consistent with the role of $\alpha$-tocopherol providing retarded lipid peroxidation when compared with vitamin Edepleted LDL, they also show that foods rich in vitamin $\mathrm{E}$ contain additional compounds that are beneficial by themselves or in conjunction with vitamin $\mathrm{E}$, and studies are warranted to determine their specific implications as antiatherogenic supplements.

\section{Metabolism}

As a consequence of its hydrophobicity, vitamin E needs a special transport system in an aqueous media, such as plasma. Different from other lipid-soluble vitamins, vitamin $\mathrm{E}$ is transported in plasma lipoproteins (51), in which it is distributed in parallel to other lipids $(10,11)$.

Intestinal absorption and metabolism of chylomicrons.- Vitamin E absorption is largely dependent upon the process gov- erning the digestion and absorption of dietary fats. Pancreatic esterases and bile acids allow the formation of micelles into which tocopherols and other hydrophobic molecules become solubilized. Vita$\min \mathrm{E}$ is absorbed in the proximal small intestine, where it is transported across the brush border by passive diffusion (41). In human, the fractional absorption of $\alpha$ tocopherol has been estimated to be $70 \%$ $(48,56)$ and in rat $65 \%(83)$, these percentages being decreased when the amount of vitamin $\mathrm{E}$ given is enhanced. There are no major differences in the fractional absorption of $\alpha$ - and $\gamma$-tocopherol whereas other tocopherols are poorly absorbed.

Within the enterocyte, vitamin $\mathrm{E}$ is packaged into chylomicrons together with triglycerides, free and esterified cholesterol, phospholipids and apoproteins, particularly apo B-48. Chylomicrons are transported from the intestine along the lymphatic pathway and secreted into the systemic circulation. In their catabolism, by the action of lipoprotein lipase (LPL) attached to the surface of the capillary endothelium in extrahepatic tissues, chylomicrons are transformed into chylomicron remnants (28). Besides hydrolyzing triglycerides in chylomicrons, LPL allow the uptake by the subjacent tissue of the hydrolytic products, free fatty acids (FFA) and glycerol, as well as part of the $\alpha$ - and $\gamma$-tocopherol carried in these lipoproteins (Fig. 5). The contribution of this process in the amount of vitamin $\mathrm{E}$ taken up by the corresponding tissue remains to be established. In the action of LPL on chylomicrons, excess surface components are transferred to high density lipoproteins (HDL), which can exchange their acquired tocopherol with other plasma lipoproteins (81, 84) (Fig. 5). Despite these interactions, the major pro- 
portion of absorbed tocopherols remains in the chylomicron remnants, which acquire apoprotein E from HDL and are then recognized by hepatic receptors for their later catabolism. In this way, vitamin E molecules from the diet are taken up by parenchymal cells in the liver.

$\alpha$-tocopherol transfer protein (TTP).The dietary $\alpha$ - and $\gamma$-tocopherols that arrive to the liver are processed in such a way that, whereas $\alpha$-tocopherol is preferentially released into the circulation and therefore driven to the peripheral tissues, $\gamma$-tocopherol is excreted in the bile. This function is believed to depend on a 31.8$\mathrm{kDa}$ cytosolic protein identified in 1975 by Catignani in the rat (20), that is only expressed in the liver and specifically binds $\alpha$-tocopherol $(100 \%)$, with much smaller affinity to $\beta$ - $(38 \%), \gamma$-tocopherol $(9 \%)$ or other related derivatives (42). Lately it was shown that this protein is also capable of transferring $\alpha$-tocopherol between liposomes and mitochondria and between liposomes and microsomes (59,

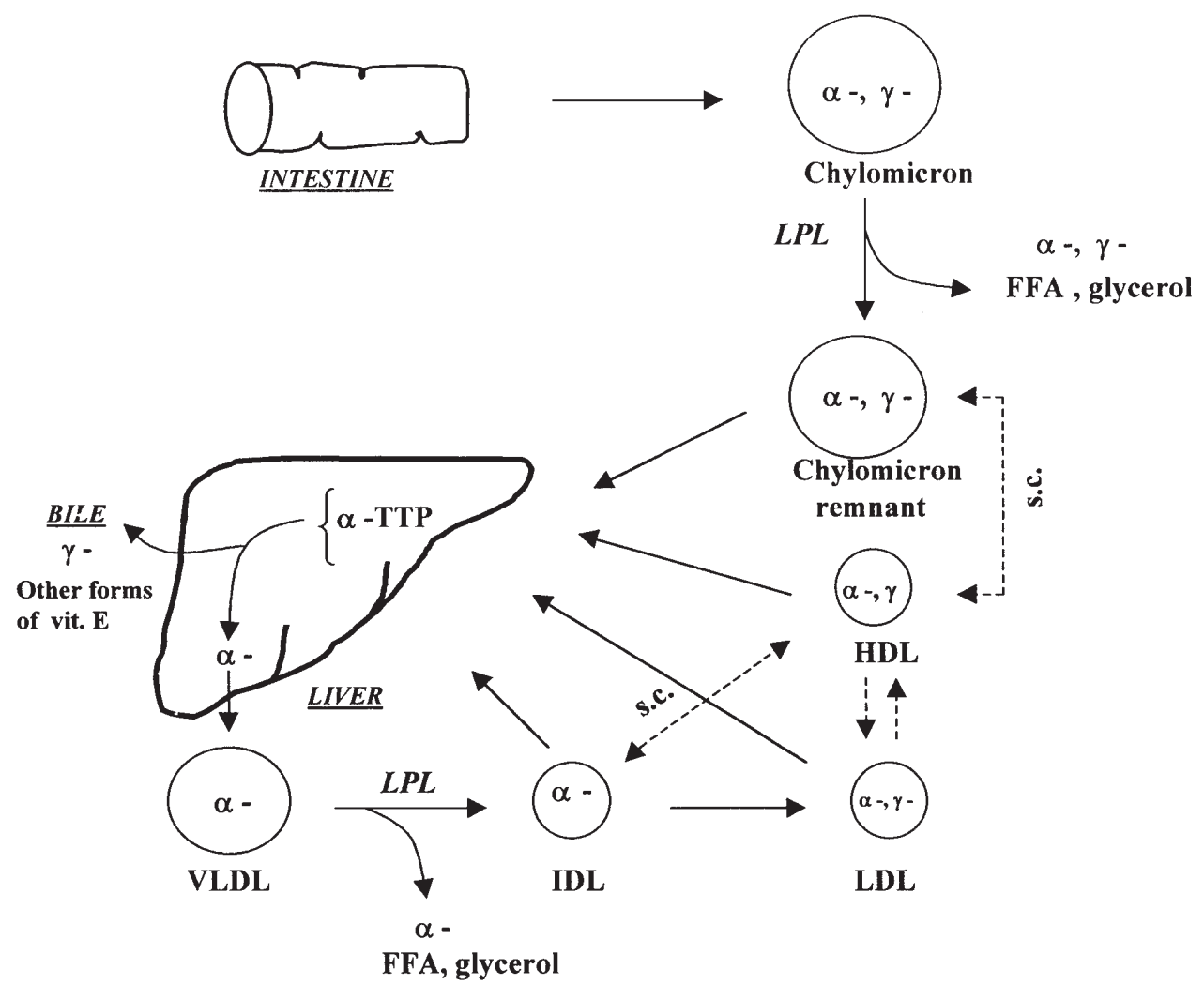

Fig. 5. Schematic transport of vitamin $E$ among plasma lipoproteins.

Continuous lines represent direct pathway, including liver uptake, whereas dashed lines represent transfer. $\mathrm{LPL}=$ lipoprotein lipase; s.c. = surface components transferred after the action of LPL on chylomicrons and VLDL; $\alpha$ - and/or $\gamma-\alpha$ - and/or $\gamma$-tocopherol; FFA $=$ free fatty acids; $\alpha$-TTP $=\alpha$-tocopherol transfer protein. Other details in the text. 
59) and it was named " $\alpha$-tocopherol transfer protein” ( $\alpha$-TTP). Its cDNA clone has been isolated in the rat (65) and in human (3).

Upon their liver uptake, chylomicron remnants are hydrolyzed within the lisosomes, from which $\alpha$-TTP binds and transfers $\alpha$-tocopherol to the endoplasmic reticulum for its incorporation into nascent VLDL (47). Thus, $\alpha$-TTP in liver discriminates among the different forms of vitamin $\mathrm{E}$, which is necessary for the incorporation of $\alpha$-tocopherol into VLDL and their subsequent release into the circulation, whereas due to its low specificity for other forms of tocopherol, including a potential excess of $\alpha$-tocopherol, it facilitates their excretion in the bile (Fig. 5). It is even believed that the system functions as if $\alpha$-TTP would preserve a certain amount of $\alpha$-tocopherol to be excreted in bile. If it was so, $\alpha$-TTP would control plasma levels of $\alpha$-tocopherol keeping them within a narrow range and this explains why treatments with high oral doses of $\alpha$-tocopherol to healthy subjects are not followed by proportional increments of its level in plasma $(32,43)$.

Liver secretion and extrabepatic metabolism.- In the liver, lipids derived from chylomicron remnants (including $\alpha$-tocopherol) combine with glycerides formed in the esterification of adipose tissue lipolytic products (FFA and glycerol) and those lipids of intrahepatic synthesis (triglycerides, phospholipids and cholesterol). These components are assembled to apoproteins, particularly apo B-100, and form nascent VLDL that are incorporated into secretion vesicles that finaly release their content to the circulation. In this process, as commented above, $\alpha$-TTP facilitates the preferential and specific incorporation of $\alpha$-tocopherol into nascent VLDL, thus compensating for the limited capacity of the liver to store vitamin E.

In the circulation, once nascent VLDL are matured by the interchange of components with HDL (50) they are catabolized by the action of LPL in a similar manner as chylomicrons, allowing the uptake of part of the triglyceride hydrolytic products (FFA and glycerol) and $\alpha$-tocopherol by the subjacent tissue. A considerable proportion of the VLDL remnants (called intermediate density lipoproteins, IDL) are returned to the liver, with the remainder being converted to LDL. In the LPL action on VLDL, excess surface components, including $\alpha$-tochopherol, are transferred to $\mathrm{HDL}$ and the vitamin $\mathrm{E}$ may then be spontaneously transferred from HDL to other lipoproteins $(81,84)$. These interactions are schematically summarized in figure 5 .

Delivery and release of $\alpha$-tocopherol to and from tissues.- The delivery of $\alpha$-tocopherol to tissues takes place by means of a number of mechanisms. Although one of them is the above commented action of LPL on triglyceride-rich lipoproteins, chylomicrons and VLDL, a relationship between the activity of this enzyme and $\alpha$-tocopherol content in certain tissues is not always established. This is the case in adipose tissue, where the majority of vitamin $\mathrm{E}$ is accumulated $(33,55)$ and which also has the highest LPL activity in the body $(14,54)$, but no correlation is found between changes in LPL activity and the tissue capacity to take up $\alpha$-tocopherol in vivo, when studied in the rat under a wide range of different conditions in either variable (unpublished observations).

Tocopherol present in other lipoproteins may be taken up by different tissues 
by means of their respective uptake throughout their corresponding receptors, via apo B-100 dependent on LDL and apo E for IDL or HDL $(16,82)$. The LDL receptor uptake of vitamin $\mathrm{E}$ appears to be important for certain tissues, including adipose tissue, adrenal glands and ovary and it must be also pointed out that liver and intestine are the tissues with the highest proportion of these receptors (31). However, although this system seems to be an important mechanism for the uptake of $\alpha$-tocopherol to these tissues, it is known that Watenabe hypercholesterolemic rabbits deficient on LDLreceptors, have tissue $\alpha$-tocopherol levels within normal range (26) which indicates the existence of alternative mechanisms for the delivery of $\alpha$-tocopherol to the tissues.

The transport of $\alpha$-tocopherol from peripheral tissues to the liver seems to be carried out by HDL in a similar manner as these lipoproteins are responsible for the reverse cholesterol transport (36). Although not completely clarified, the release of $\alpha$-tocopherol from adipose tissue seems to play an important role in keeping plasma levels under deficiency conditions. In fact, in contrast to what occurs with the products of lipolysis, tocopherol does not decrease in adipose tissue when food intake is reduced in obese subjects (66) or under fasting conditions in subjects with normal weight (15). These findings indicate the existence of a mechanism for the release of $\alpha$-tocopherol from adipose tissue different from the one normally used for the release of triglycerides. However, the content of $\alpha$-tocopherol in peripheral nerves has been correlated to its concentration in adipose tissue (46) and the concentration of $\alpha$-tocopherol in adipose tissue of vitamin E-deficient patients has been shown to be lower than normal (45), all of which indicates the capacity of adipose tissue to release $\alpha$ tocopherol.

\section{Perspectives and open questions}

After more than 75 years since its discovery, we have now substantial information on the action, effects and metabolism of vitamin E, but still there are several questions open. Although a number of basic research and epidemiological studies have improved the understanding of many aspects of vitamin $\mathrm{E}$ physiology and indicate that an increased intake may be beneficial to maintain optimal health, there is no conclusive answer to certain questions. In relation to its metabolism, additional studies are required to elucidate the pathways for the conversion of $\alpha$-tocopherol into its oxidation products and their potential physiological (and clinical) relevance, to understand the mechanism of $\alpha$ tocopherol uptake and release by certain tissues, as well as the specific differences in the biopotency of the individual tocopherols with defined isomeres and stereochemistry. A special issue that needs to be definitely clarified is the question of the potential positive or negative effects of vitamin $\mathrm{E}$ on atherosclerosis. Benefits seen in observational epidemiology are not always followed by benefits in vitamin $\mathrm{E}$ supplement studies. The antioxidant effects of vitamin $\mathrm{E}$ may be counteracted by pro-oxidant activity under certain conditions and there is even evidence of adverse effects following the intake of high doses. Thus, benefit to risk relationship has to be considered before advising its supplementation. Foods containing small or moderate amounts of vitamin E, including olive oil, seem to provide greater benefits than larger doses of vitamin $\mathrm{E}$ alone. Besides their specific effects 
on endogenous $\alpha$-tocopherol kinetics, it may be possible that other antioxidant compounds in conjunction with vitamin $\mathrm{E}$ may be required to warrant a beneficial response, but further studies are needed to support this possibility.

\section{Acknowledgements}

We thank Milagros Morante for her excellent technical assistance and Dr. Beatriz Ramos for editorial help. This study has been supported by grants from Fondo de Investigación Sanitaria, Instituto de Salud Carlos III (\#99/0205) and Universidad San Pablo-CEU (\#6/99 and 19/99) of Spain and from the European Community (FATLINK, FAIR-CT-984141).

E. HERRERA y C. BARBAS. Vitamina E: acción, metabolismo y perspectivas (minirrevisión). J. Physiol. Biochem., 57 (1), 43-56, 2001.

La vitamina $E$ natural incluye cuatro tocoferoles y cuatro tocotrienoles, de los cuales el RRR- $\alpha$-tocoferol es el más abundante en la naturaleza y presenta la máxima actividad biológica. Aunque es el principal antioxidante liposoluble del organismo, no todas las propiedades de la vitamina E pueden achacarse a esta acción. Como antioxidante, la vitamina $\mathrm{E}$ actúa en las membranas celulares donde evita la propagación de las reacciones de los radicales libres, aunque también puede ejercer acciones pro-oxidantes. En la reacción del radical $\alpha$ tocoferilo con otros radicales libres se forman compuestos no-radicales, que se conjugan al ácido glucurónico y son excretados por la bilis o la orina. La vitamina $\mathrm{E}$ se transporta en las lipoproteínas plasmáticas. Tras su absorción intestinal, la vitamina $\mathrm{E}$ se asocia a los quilomicrones, que a través de la vía linfática son secretados a la circulación sistémica. Por acción de la lipoproteína lipasa (LPL), parte de los tocoferoles presentes en los quilomicrones son transferidos a los tejidos extrahepáticos, y los remanentes de los quilomicrones transportan los tocoferoles restantes al hígado. En el hígado, por acción de la "proteína transferidora de $\alpha$-tocoferol”, una parte sustancial del $\alpha$-tocoferol es incorporado a las VLDL nacientes, mientras que el resto, junto a las otras formas de vitamina E, es eliminado por la bilis. Una vez secretadas a la circulación, las VLDL son convertidas en IDL y LDL por acción de la LPL, y compuestos de superficie (incluyendo el $\alpha$-tocoferol) son transferidos a las HDL. Además de la acción de la LPL, la llegada del $\alpha$-tocoferol a los tejidos tiene lugar a través de la captación de las lipoproteínas, mediada por sus respectivos receptores. Aunque se cuenta con una amplia información sobre la acción, los efectos y el metabolismo de la vitamina E, aún hay pendientes numerosas cuestiones por dilucidar, y de entre ellas cabe destacar la interacción de la vitamina $\mathrm{E}$ con otros antioxidantes, lo que puede explicar cómo alimentos que contienen pequeñas proporciones de aquella producen mayores beneficios que grandes dosis de la vitamina sola.

Palabras clave: Vitamina E, $\alpha$-Tocoferol, Antioxidantes, Lipoproteínas..

\section{References}

1. Amusquivar, E., Rupérez, F. J., Barbas, C. and Herrera, E. (2000): J. Nutr., 130, 2855-2865.

2. Aratri, E., Spycher, S. E., Breyer, I. and Azzi, A. (1999): FEBS Lett., 447, 91-94.

3. Arita, M., Sato, Y., Miyata, A., Tanabe, T., Takahashi, E., Kayden, H. J., Arai, H. and Inoue, K. (1995): Biochem. J., 306, 437-443.

4. Azzi, A., Breyer, I., Feher, M., Pastori, M., Ricciarelli, R., Spycher, S., Staffieri, M., Stocker, A., Zimmer, S. and Zingg, J.-M. (2000): J. Nutr., 130, 1649-1652.

5. Azzi, A., Boscoboinik, D., Chatelain, E., Özer, N. K. and Stuble, B. (1993): Mol. Aspects Med., 14, 265-271.

6. Azzi, A., Boscoboinik, D., Clément, S., Marilley, D., Özer, N. K., Ricciarelli, A. and Tasinato, A. (1997): Prostaglandins Lenkot. Essent. Fatty Acids, 57, 507-514.

7. Azzi, A. and Stocker, A. (2000): Prog. Lipid Res., 39, 231-255.

8. Banks, P., Bartley, W. and Birt, L. M. (1978): "The biochemistry of the tissues", John Wiley \& Sons, Chichester.

9. Bauernfeind, J. (1980): In "Vitamin E: A comprehensive treatise" (L. J. Machlin, ed.), MarcelDekker, New York, pp. 99-167.

10. Behrens, W. A., Thompson, J. N. and Madere, R. (1982): Am. J. Clin. Nutr., 35, 691-696. 
11. Bjornson, L. K., Kayden, H. J., Miller, E. and Moshell, A. N. (1976): J. Lipid. Res., 17, 343-352.

12. Bowry, V. W., Ingold, K. U. and Stocker, R. (1992): Biochem. J., 288, 341-344.

13. Bramley, P. M., Elmadfa, I., Kafatos, A., Kelly, F. J., Manios, Y., Roxborough, H. E., Schuch, W., Sheehy, P. J. A. and Wagner, K. H. (2000) J. Sci. Food Agric., 80, 913-938.

14. Braun, J. E. A. and Severson, D. L. (1992): Biochem. J., 287, 337-347.

15. Brouwer, D. A., Molin, F., van Beusekom, C. M., van Doormaal, J. J. and Musklet, F. A. (1998): Clin. Chim. Acta, 277, 127-139.

16. Brown, M. S. and Goldstein, J. L. (1986): Science, 232, 34-47.

17. Bunyan, J., McHale, D., Green, J. and Marcinkiewicz, S. (1961): Br. J. Nutr., 15, $253-$ 257.

18. Burton, G. W. and Ingold, K. U. (1986): Acc. Chem. Res., 19, 194-201.

19. Carpenter, D. (1985): Sem. Neurol., 5, 283-287.

20. Catignani, G. L. (1975): Biochem. Biophys. Res. Commun., 67, 66-72.

21. Chan, A. and Leith, M. K. (1981): Am. J. Clin. Nutr., 34, 2341-2347.

22. Chan, A. C. (1998): J. Nutr., 128, 1593-1596.

23. Chan, A. C., Tran, K., Pyke, D. D. and Powell, W. S. (1989): Biochim. Biophys. Acta, 1005, 265269.

24. Chan, A. C., Wagner, M., Kennedy, C., Mroske, C., Proulx, P., Laneuville, O., Tran, K. and Choy, P. C. (1998): Aktuel. Ernabr-Med., 23, 18.

25. Chiku, S., Hamamura, K. and Nakamura, T. (1984): J. Lipid Res., 25, 40-48.

26. Cohn, W. and Kuhn, H. (1989): Ann. N. Y. Acad. Sci., 570, 61-71.

27. Cominacini, L., Garbin, U., Pasini, A. F., Davoli, A., Campagnola, M., Contessi, G.B., Pastorino, A. M. and Lo Cascio, V. (1997): Free Radic. Biol. Med., 22, 117-127.

28. Deckelbaum, R. J., Ramakrishnan, R., Eisenberg, S. and Olivecrona, T. (1992): Biochemistry, 31, 8544-8551.

29. Devaraj, S., Li, D. and Jialal, I. (1996): J. Clin. Invest., 98, 756-763.

30. Dieber-Rotheneder, M., Puhl, H., Waeg, G., Striegl, G. and Esterbauer, H. (1991): J. Lipid. Res., 32, 1325-1332.

31. Dietschy, J. M., Spady, D. K. and Stange, E. F. (1983): Biochem. Soc. Trans., 11, 639-641.

32. Dimitrov, M. V., Meyer, C., Gilliland, D. and Ruppenthal, M. (1991): J. Clin. Nutr., 53, 723729.
33. Drevon, C. A. (1991): Free. Radic. Res. Commun., 14, 229-246.

34. Evans, H. M. and Bishop, K. S. (1922): Science, 56, 650-651.

35. Faruqi, R., de la Motte, C. and DiCorleto, P. E. (1994): J. Clin. Invest., 94, 592-600.

36. Francis, G. A. and Perry, R. J. (1999): Clin. Chim. Acta, 286, 219-230.

37. Freedman, J. E., Farhat, J. H., Loscalzo, J. and Keaney, J. F. (1996): Circulation, 94, 2434-2440.

38. Gaby, S. K. and Machlin, L. J. (1991): In "Vitamin intake and health: a scientific review”, (S. K. Gaby, A. Bendich, V. N. Singh and L. J. Machlin, eds.). Marcel Dekker, New York, pp. 71-95.

39. Gaziano, J. M. (1996): Nutrition, 12, 583-588.

40. Gey, K. F., Puska, P., Jordan, P. and Moser, U. K. (1991): Am. J. Clin. Nutr., 53, 326S-334S.

41. Hollander, D., Rim, E. and Muralidhara, K. S. (1975): Gastroenterology, 68, 1492-1499.

42. Hosomi, A., Arita, M., Sato, Y., Kiyose, C., Ueda, T., Igarashi, O., Arai, H. and Inoue, K. (1997): FEBS Lett., 409, 105-108.

43. Jialal, I. and Grundy, S. M. (1992): J. Lipid. Res., 33, 899-906.

44. Kamal-Eldin, A. and Appelquist, L. A. (1996): Lipids, 31, 671-701.

45. Kayden, H. J. (1983): In "Biology of vitamin E" (R. Porter and J. Whelan, eds.). Pittman Books, Ltd, London, pp. 70-91.

46. Kayden, H. J., Hatam, L. J. and Traber, M. G. (1983): J. Lipid. Res., 24, 652-656.

47. Kayden, H. J. and Traber, M. G. (1993): J. Lipid. Res., 34, 343-358.

48. Kelleher, J. and Losowsky, M. S. (1970): Br. J. Nutr., 24, 1033-1047.

49. Kontush, A., Finckh, B., Karten, B., Kohlschütter, A. and Beisiegel, U. (1996): J. Lipid Res., 37, 1436-1448.

50. Lasunción, M. A., Gómez-Coronado, D. and Herrera, E. (1992): In "Temas actuales en hiperlipidemias y arteriosclerosis” (J. Rubíes-Prat, ed.). Espaxs, Publicaciones Médicas, Barcelona, pp. 39-64.

51. Lewis, L. A., Quaife, M. L. and Page, I. H. (1954): Am. J. Physiol., 178, 221-222.

52. Liebler, D. C., Baker, P. F. and Kaysen, K. L. (1990): J. Am. Chem. Soc., 112, 6995-7000.

53. Liebler, D. C., Burr, J. A. and Ham, A. J. L. (1999): Methods Enzymol. 299, 309-318.

54. López-Luna, P., Olea, J. and Herrera, E. (1994): Biochim. Biophys. Acta, Lipids Lipid Metab., 1215, 275-279.

55. Machlin, I. J. (1984): In "Handbook of vitamins" (I. J. Machlin, ed.). Marcel Dekker, New York and Basel, pp. 99-145. 
56. MacMahon, M.T. and Neale, G. (1970): Clin. Sci., 38, 197-210.

57. McLaughlin, P. J. and Weihrauch, J. L. (1979): J. Am. Diet. Assoc., 75, 647-665.

58. Miki, M., Tamai, H., Mino, M., Yamamoto, Y. and Niki, E. (1987): Arch. Biochem. Biophys., 258, 373-380.

59. Murphy, D. J. and Mavis, R. D. (1981): J. Biol. Chem.: 256, 10464-10468.

60. Nagaoka, S., Inoue, M., Nishioka, C., Nishioku, Y., Tsunoda, S., Ohguchi, C., Ohara, K., Mukai, K. and Nagashima, U. (2000): J. Phys. Chem. B, 104, 856-862.

61. Özer, N. K., Sirikci, Ö., Taha, S., San, T., Moser, U. and Azzi, A. (1998): Free Rad. Biol. Med., 24, 226-233.

62. Parthasarathy, S., Santanam, N., Ramachandran, S. and Meilhac, O. (1999): J. Lipid. Res., 40, 2143 2157.

63. Reaven, P. D., Khouw, A., Beltz, W. F., Parthasarathy, S. and Witztum, J. L. (1993): Arterioscler. Thromb., 13, 590-600.

64. Rota, S., McWilliam, N. A., Baglin, T. P. and Byrne, C. D. (1998): Blood, 91, 508-515.

65. Sato, Y., Arai, H., Miyata, A., Tokita, S., Yamamoto, K., Tanabe, T. and Inoue, K. (1993): J. Biol. Chem., 268, 17705-17710.

66. Schaefer, E. J., Woo, R., Kibata, M., Bjornsen, L. and Schreibman, P. H. (1983): Am. J. Clin. Nutr., 37, 749-754.

67. Schonfeld, A., Schultz, M., Petrzika, M. and Gassmann, B. (1993): Nabrung, 37, 498-500.

68. Schuelke, M., Mayatepek, E., Inter, M., Becker, M., Pfeiffer, E., Speer, A., Hübner, C. and Finckh, B. (1999): J. Pediatr., 134, 240-244.

69. Schultz, M., Leist, M., Petrzida, M., Gassmann, B. and Brigelius-Flohé, R. (1995): Am. J. Clin. Nutr., 62 (Suppl), 1527S-1543S.

70. Schultz, M., Leist, M., Petrzika, M., Gassmann, B. and Brigelius-Flohé, R. (1995): Am. J. Clin. Nutr., 62, 1527S-1534S.

71. Scott, G. (1994): Biochem. Soc. Symp., 61, 235246.

72. Sheppard, A. J., Pennington, J. A. T. and Weihrauch, J. L. (1993): In "Vitamin E in health and disease" (L. Packer and J. Fuchs, eds.). Marcel Dekker, Inc., New York, pp. 9-31.
73. Sokol, R.J., Guggenheim, M., Iannaccone, S.T., Barkhaus, P.E., Miller, C., Silverman, A., Balistreri, W. F. and Heubi, J. E. (1985): N. Engl. J. Med., 313, 1580-1586.

74. Stephens, N. G., Parsons, A., Schofield, P. M., Kelly, F., Cheeseman, K., Mitchinson, M. J. and Brown, M. J. (1996): Lancet 347, 781-786.

75. Stocker, R. (1999): Trends Biochem. Sci., 24, 219223.

76. Swanson, J. E., Ben, R. N., Burton, G. W. and Parker, R. S. (1999): J. Lipid Res., 40, 665-671.

77. Szczeklik, A., Gryglewski, R. J., Domagala, B., Dworski, R. and Basista, M. (1985): Thromb. Haemostasis, 30, 425-430.

78. Tappel, A. L. (1962): Vitam. Horm., 20, 493-510.

79. Teupser, D., Thiery, J. and Seidel, D. (1999): Atherosclerosis, 144, 109-115.

80. The alpha-tocopherol beta carotene cancer prevention study group (1994): N. Engl. J. Med., 330, 1029-1035.

81. Traber, M. G. (1996): In "Handbook of antioxidants” (E. Cadenas and L. Packer, eds.). MarcelDekker, New York, pp. 43-61.

82. Traber, M. G. and Kayden, H. J. (1984): Am. J. Clin. Nutr., 40, 747-751.

83. Traber, M. G., Kayden, H. J., Green, J. B. and Green, M. H. (1986): Am. J. Clin. Nutr., 44, 914923.

84. Traber, M. G., Lane, J. C., Lagmay, N. and Kayden, H. J. (1992): Lipids, 27, 657-663.

85. Upston, J. M., Terentis, A. C. and Stocker, R. (1999): FASEB J., 13, 977-994.

86. Viana, M., Barbas, C., Bonet, B., Bonet, M. V., Castro, M., Fraile, M. V. and Herrera, E. (1996): Atherosclerosis, 123, 83-91.

87. Viana, M., Herrera, E. and Bonet, B. (1996): Diabetologia, 39, 1041-1046.

88. Vogelsang, A. and Shute, E. V. (1946): Nature, 157,772 .

89. Wechter, W. J., Kantoci, W. J. D., Murray, Jr., E. D., DiAmico, D. C., Jung, M. E. and Wang, W.H. (1996): Proc. Natl. Acad. Sci. USA, 93, 60026007.

90. Whitney, E. N., Hamilton, E. M. N. and Rolfes, S. R. (1990): “Understanding nutrition” (St. Paul, ed.), West Publishing Co., Minn.

91. Wu, S. H., Oldfield, J. E., Whanger, P. D. and Weswig, P. H. (1973): Biol. Reprod., 8, 625-629. 